\title{
Nutrient Studies of Wheat as Influenced by Different Nitrogen Management Practices
}

\author{
Meena Sewhag ${ }^{1}$, Shweta $^{1}$, Parveen Kumar ${ }^{1}$, Manoj Kumar Sharma ${ }^{2 *}$, \\ Neelam ${ }^{1}$ and Uma Devi ${ }^{1}$ \\ ${ }^{1}$ Department of Agronomy, ${ }^{2}$ Department of Soil Science, CCS HAU, Hisar, Haryana, India \\ *Corresponding author
}

\section{Keywords}

Nutrient Studies,

Wheat,

Nitrogen

Management

Article Info

Accepted:

04 October 2020

Available Online:

10 November 2020

\section{A B S T R A C T}

A study was conducted during rabi season of 2017-18 at Agronomy Research Area of CCS Haryana Agricultural University, Hisar to study the effects of different sources and levels of nitrogen application on nutrient content and uptake of wheat. The soil of the experimental field was sandy loam in texture, neutral in reaction, low in organic carbon and available nitrogen, medium in available potassium and high in available potassium .The experiment was laid out in a split plot design with four nitrogen sources [Ordinary Urea (1/2 Basal and $1 / 2$ at first irrigation), Ordinary Urea (1/2 Basal $+1 / 4$ first irrigation $+1 / 4$ heading), Neem Coated Urea ( $1 / 2$ Basal $+1 / 2$ first irrigation) and Neem Coated Urea ( $1 / 2$ Basal $+1 / 4$ first irrigation $+1 / 4$ heading $)]$ in main plots and four nitrogen levels $(80 \%, 90 \%$, $100 \% \mathrm{RDN}$ and $110 \% \mathrm{RDN}$ ) in sub plots replicated thrice. Overall results depicted that application of three split application of neem coated urea (1/2 Basal $+1 / 4$ first irrigation $+1 / 4$ heading)] recorded significantly higher $\mathrm{N}$ and $\mathrm{K}$ content in grain and $\mathrm{N}$ content in straw of wheat. Higher $\mathrm{N}$ uptake in grain, straw, total N, P and K uptake and K uptake by straw was also recorded with three split application of neem coated urea. However P content and uptake in grain and straw of wheat and $\mathrm{K}$ content in straw and $\mathrm{K}$ uptake in grain were not influenced significantly by varying nitrogen sources. Increasing nitrogen levels from 80 to $110 \%$ RDN resulted in significantly higher $\mathrm{N}$ content in grain and straw and also higher $\mathrm{N}$ uptake in grain, straw and total $\mathrm{N}$ uptake of wheat. Similarly P and K content in grain and $\mathrm{P}$ uptake by grain and total $\mathrm{P}$ uptake of wheat increases significantly with increasing levels of nitrogen from 80 to $110 \%$ RDN. There was no significant influence of various nitrogen levels on $\mathrm{P}$ content and uptake by straw, $\mathrm{K}$ content in straw and $\mathrm{K}$ uptake by grain of wheat. There was no significant difference due to application of various $\mathrm{N}$ levels and sources on N, P and K status of soil after harvesting of wheat.

\section{Introduction}

Among the various food crops, cereals are the kingpins towards transformation of agriculture in India from scarcity to sufficiency. Wheat (Triticum aestivum L.) is the second most important crop of India after rice contributing $1 / 3$ rd to total food grain production (Kumari and Singh, 2016). Though current wheat production in India is sufficient to meet its demand, but it has to be increased to 105 million tonnes per annum by 
2025 to meet the increasing demand (Prasad 2011) for which there is a need to develop proper production technology. At present, the world population is around 7 billion people and is predicted to rise to around 9.5 billion by 2050 . In just 100 years, world population has increased around fourfold. Global warming has resulted in a significant reduction in food production (IPCC 2014).

High-yielding wheat varieties exhaust soil nutrients, limiting crop production and restrict upward growth of productivity. The farmers ${ }^{\text {ee }}$ perception of nutrient management is the use of major nutrients like $\mathrm{N}, \mathrm{P}$ and $\mathrm{K}$. Unbalanced application of nutrients for longer duration has led to challenging emergence of multi-nutrient deficiencies in soils under the rice-wheat system (Ladha et al., 2009).

Generally, all the agricultural soils are grossly deficient in nitrogen and the wheat crop responds to applied nitrogen. The response of any crop to applied nitrogenous fertilizer depends on soil type, soil fertility status, crop and soil management practices, crop variety and also on the method and source of fertilizer application. Wheat is very responsive to nitrogen fertilization and very sensitive to insufficient nitrogen dose. Majority of urea in cereals is applied at the time of sowing when nitrogen utilized by the crop is very less so most of the applied nitrogen is wasted whereas at vegetative growth stage when the demand of nitrogen is higher the crop suffered mostly by nutrient stress condition. Neem Coated Urea (NCU) delay nitrification process or have other slowrelease properties that will allow urea to better feed plant need, thereby increasing $\mathrm{N}$-use efficiency and reducing the emission of nitrous oxide. Nutrient uptake in crops is largely dependent on the growth and development of plants. However, concentration of various nutrients in the plant system also affects their total uptake. There is an urgent need to study effect of various nutrient management practices to get maximum benefit and to improve wheat nutrient content and uptake by grain and straw.

This study is very helpful in determining the stage of greatest hunger or nutritional requirements of wheat which can help in fixing up manurial schedule for maximum production. The uptake of nutrients and composition of plants is greatly influenced by soil types, climatic conditions, nature of crops and amount of fertilizers applied. The present study was initiated to obtain this information for wheat crop grown under Hisar condition. Keeping these points in view, the present investigation was carried out with the objective to study the nutrient content and uptake of wheat as influenced by different nitrogen management practices.

\section{Materials and Methods}

To analyze the influence of various nitrogen management practices on nutrient content and uptake pattern by wheat a field experiment was carried out during rabi season of 2017-18 at Agronomy Research Area of Chaudhary Charan Singh Haryana Agricultural University, Hisar. The goal of this paper was to investigate the effect of four different sources and levels of nitrogen application on nutrient studies of wheat. The experiment was laid out in a split plot design with four nitrogen sources [Ordinary Urea $(1 / 2$ Basal and $1 / 2$ at first irrigation), Ordinary Urea ( $1 / 2$ Basal $+1 / 4$ first irrigation $+1 / 4$ heading), Neem Coated Urea ( $1 / 2$ Basal $+1 / 2$ first irrigation) and Neem Coated Urea $(1 / 2$ Basal $+1 / 4$ first irrigation $+1 / 4$ heading)] in main plots and four nitrogen levels (80\%, $90 \%, 100 \%$ RDN and $110 \%$ RDN) in sub plots replicated thrice. The climate of Hisar $\left(29^{\circ} 10^{\prime} \mathrm{N}\right.$ latitude and $75^{\circ} 46^{\prime} \mathrm{E}$ longitude at an elevation of $215.2 \mathrm{~m}$ above mean sea level.) is sub- 
tropical, semi-arid with an average annual rainfall of around $450 \mathrm{~mm}$ of which, 70-80 per cent is received during monsoon period i.e., July to September and the rest is received in showers of cyclic rains during the winter and spring seasons. The soil organic carbon, $\mathrm{pH}$, available $\mathrm{P}$ and available $\mathrm{K}$ were 0.43 , $7.8,17 \mathrm{~kg} \mathrm{ha}^{-1}$ and $375 \mathrm{~kg} \mathrm{ha}^{-1}$, respectively, before sowing in November 2017. Experimental field was prepared thoroughly by two ploughings and one planking, followed by pre-sowing irrigation. A basal dose of $60 \mathrm{~kg} \mathrm{P}_{2} \mathrm{O}_{5} / \mathrm{ha}$ was applied to all the experimental plots at sowing as single superphosphate through seed-cum-fertilizer drill. Wheat seed was sown on $2^{\text {nd }}$ December 2017 and harvested on 20 April 2018. Wheat variety 'WH 1105 ' was sown with row to row spacing of $20 \mathrm{~cm}$. The other agronomic practices like irrigation, insect-pests control and weed control measures were done as per recommended package of practices of CCSHAU, Hisar. All yield attributes were recorded periodically on randomly selected and tagged plants. The uptake of nitrogen, phosphorous and potassium ( $\mathrm{kg} / \mathrm{ha})$ was calculated on the basis of nutrient content on dry weight basis of grain and straw. Oven dried grain and straw samples weighed 0.2 and $0.5 \mathrm{~g}$, respectively were digested in diacid mixture of $\mathrm{H}_{2} \mathrm{SO}_{4}$ and $\mathrm{HClO}_{4}$ in the ratio of 9:1 for nutrients (N, P) estimation. After the digestion, a known volume was made with distilled water and stored after filtration through Whatman filter paper No. 42 in well washed plastic bottles. Nitrogen content in digested plant material was determined by Nessler's reagent method. Phosphorus content was determined by Vanadomolybdo phosphoric acid yellow colour method (Koening and Jackson, 1942), respectively.

Nutrient uptake was computed as below:

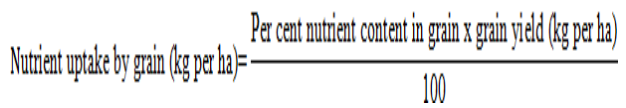

Nutrient uptake by straw (kg per ha) $=\frac{\text { Per cent nutrient content in straw } x \text { straw yield (kg per ha) }}{100}$

The total uptake of nitrogen, phosphorus and potassium at harvest was computed by adding the nutrient uptake by grain and straw.

\section{Results and Discussion}

\section{Nutrient studies}

\section{Nitrogen content and uptake}

The data pertaining to nitrogen content (per cent) and uptake $\left(\mathrm{kg} \mathrm{ha}^{-1}\right)$ in grains and straw presented in table 1 indicate that $\mathrm{N}$ content and uptake by grain and straw of wheat was affected significantly due to varying $\mathrm{N}$ sources and levels. Application of three split application of neem coated urea (1/2 Basal + 1/4 first irrigation $+1 / 4$ heading)] recorded significantly higher $\mathrm{N}$ content in grain and straw of wheat. However the difference in $\mathrm{N}$ content in grain and straw in 2 split and 3 split neem coated urea was not significant. Higher $\mathrm{N}$ uptake in grain, straw and total $\mathrm{N}$ uptake was also recorded with three split application of neem coated urea as compared to other treatments.

$\mathrm{N}$ uptake in grain as well as in straw was recorded highest with the application of three split application of neem coated urea ( $1 / 2$ Basal $+1 / 4$ first irrigation $+1 / 4$ heading)] with total $\mathrm{N}$ uptake of $158.19 \mathrm{~kg} \mathrm{ha}^{-1}$. Lowest $\mathrm{N}$ content in grain and straw was recorded with the application of two split application of ordinary urea $(1 / 2$ Basal and $1 / 2$ at first irrigation).

Increasing levels of nitrogen from 80 to 110 $\%$ RDN resulted in significantly higher $\mathrm{N}$ content in grain and straw of wheat. Similarily, uptake of $\mathrm{N}$ in grain, straw and total $\mathrm{N}$ uptake increased significantly with increase in $\mathrm{N}$ levels from 80 and $110 \%$ RDN. 
Application of higher $\mathrm{N}$ levels might have increased the cation exchange capacity of roots thereby increasing the nutrient absorption and cellular contents in plants. Similar were the findings of Kumar et al., (2002). Increase in uptake of $\mathrm{N}$ was mainly due to the fact that nutrient uptake followed the yield pattern which increased with increasing $\mathrm{N}$ levels. Taalab et al., (2015) and Muurinen (2007) also reported significant increase in straw nitrogen uptake with increased $\mathrm{N}$ levels.

Table.1 Effect of different nitrogen levels and sources on nitrogen content and uptake of wheat

\begin{tabular}{|c|c|c|c|c|c|}
\hline \multirow[t]{2}{*}{ Treatments } & \multicolumn{2}{|c|}{$\mathrm{N}$ content $(\%)$} & \multicolumn{3}{|c|}{ N uptake $\left(\mathrm{kg} \mathrm{ha}^{-1}\right)$} \\
\hline & Grain & Straw & Grain & Straw & Total \\
\hline \multicolumn{6}{|l|}{ Nitrogen sources } \\
\hline Ordinary Urea (2-split) & 1.90 & 0.601 & 90.29 & 42.56 & 132.84 \\
\hline Ordinary Urea (3-split) & 1.98 & 0.603 & 100.54 & 42.87 & 143.41 \\
\hline $\begin{array}{l}\text { Neem Coated Urea (2- } \\
\text { split) }\end{array}$ & 2.02 & 0.608 & 105.36 & 43.24 & 148.60 \\
\hline $\begin{array}{l}\text { Neem Coated Urea (3- } \\
\text { split) }\end{array}$ & 2.05 & 0.700 & 107.81 & 50.38 & 158.19 \\
\hline$C D(p=0.05)$ & 0.06 & 0.07 & 4.38 & 2.87 & 6.77 \\
\hline \multicolumn{6}{|l|}{ Nitrogen levels } \\
\hline $80 \%$ RDN (120 kg N & 1.93 & 0.598 & 88.63 & 41.02 & 129.64 \\
\hline $90 \%$ RDN (135 kg N) & 1.96 & 0.603 & 95.90 & 42.86 & 138.76 \\
\hline $100 \%$ RDN $(150 \mathrm{~kg} N)$ & 2.02 & 0.609 & 108.72 & 44.06 & 152.77 \\
\hline $110 \%$ RDN (165 kg N) & 2.04 & 0.702 & 110.94 & 51.23 & 162.17 \\
\hline $\mathrm{CD}(\mathrm{p}=0.05)$ & 0.07 & 0.08 & 5.08 & 2.83 & 7.18 \\
\hline
\end{tabular}

Table.2 Effect of different nitrogen levels and sources on phosphorus content and uptake of wheat

\begin{tabular}{|l|c|c|c|c|c|}
\hline \multirow{2}{*}{ Treatments } & \multicolumn{3}{|c|}{ P content (\%) } & \multicolumn{3}{c|}{ P uptake (kg ha $\left.\mathbf{- 1}^{\mathbf{1}}\right)$} \\
\hline & Grain & Straw & Grain & Straw & Total \\
\hline Nitrogen sources & & & & & \\
\hline Ordinary Urea (2-split) & 0.33 & 0.139 & 15.68 & 9.84 & 25.54 \\
\hline Ordinary Urea (3-split) & 0.33 & 0.140 & 16.76 & 9.95 & 26.72 \\
\hline Neem Coated Urea (2-split) & 0.34 & 0.141 & 17.73 & 10.03 & 27.74 \\
\hline Neem Coated Urea (3-split) & 0.35 & 0.141 & 18.41 & 10.15 & 28.54 \\
\hline CD (p= 0.05) & NS & NS & NS & NS & 2.04 \\
\hline Nitrogen levels & & & & & \\
\hline $\mathbf{8 0 \% ~ R D N ~ ( 1 2 0 ~ k g ~ N ~}$ & 0.32 & 0.138 & 14.69 & 9.47 & 24.18 \\
\hline $\mathbf{9 0} \%$ RDN (135 kg N) & 0.34 & 0.140 & 16.64 & 9.95 & 26.57 \\
\hline $\mathbf{1 0 0} \%$ RDN (150 kg N) & 0.34 & 0.141 & 18.30 & 10.20 & 28.52 \\
\hline $\mathbf{1 1 0} \%$ RDN (165 kg N) & 0.35 & 0.142 & 19.03 & 10.36 & 29.38 \\
\hline CD $\mathbf{( p = 0 . 0 5 )}$ & 0.02 & NS & 1.45 & NS & 2.77 \\
\hline
\end{tabular}


Table.3 Effect of different nitrogen levels and sources on potassium content and uptake of wheat

\begin{tabular}{|l|c|c|c|c|c|}
\hline \multirow{2}{*}{ Treatments } & \multicolumn{3}{|c|}{ K content (\%) } & \multicolumn{3}{c|}{ K uptake (kg ha-1 } \\
\cline { 2 - 6 } & Grain & Straw & Grain & Straw & Total \\
\hline Nitrogen sources & & & & & \\
\hline Ordinary Urea (2-split) & 0.441 & 1.04 & 20.96 & 73.64 & 94.62 \\
\hline Ordinary Urea (3-split) & 0.463 & 1.07 & 23.51 & 76.07 & 99.58 \\
\hline $\begin{array}{l}\text { Neem Coated Urea } \\
\text { split) }\end{array}$ & 0.483 & 1.11 & 25.19 & 78.94 & 104.16 \\
\hline $\begin{array}{l}\text { Neem Coated Urea } \\
\text { split) }\end{array}$ & & & & & \\
\hline CD (3- & 0.491 & 1.15 & 25.82 & 82.77 & 108.57 \\
\hline Nitrogen levels & & & & & \\
\hline $\mathbf{8 0 \% ~ R D N ~ ( 1 2 0 ~ k g ~ N ~}$ & 0.009 & NS & NS & 2.62 & 7.24 \\
\hline $\mathbf{9 0} \%$ RDN (135 kg N) & 0.471 & 1.09 & 23.05 & 77.48 & 100.50 \\
\hline $\mathbf{1 0 0} \%$ RDN (150 kg N) & 0.476 & 1.11 & 25.62 & 80.30 & 105.93 \\
\hline $\mathbf{1 1 0} \%$ RDN (165 kg N) & 0.480 & 1.12 & 26.10 & 81.74 & 107.83 \\
\hline CD (p= 0.05) & 0.006 & NS & NS & 3.34 & 4.50 \\
\hline
\end{tabular}

Table.4 Effect of different nitrogen levels and sources on soil N, P and K status

\begin{tabular}{|c|c|c|c|}
\hline Treatments & $N\left(\operatorname{kg~ha~}^{-1}\right)$ & $\mathrm{P}_{2} \mathrm{O}_{5}\left(\mathrm{~kg} \mathrm{ha}^{-1}\right)$ & $K_{2} O\left(\mathrm{~kg} \mathrm{ha}^{-1}\right)$ \\
\hline \multicolumn{4}{|l|}{ Nitrogen sources } \\
\hline Ordinary Urea (2-split) & 110.81 & 12.31 & 253.67 \\
\hline Ordinary Urea (3-split) & 111.83 & 14.36 & 244.79 \\
\hline Neem Coated Urea (2-split) & 113.75 & 15.82 & 265.92 \\
\hline Neem Coated Urea (3-split) & 114.05 & 16.65 & 259.45 \\
\hline $\mathrm{CD}(\mathbf{p}=\mathbf{0 . 0 5})$ & NS & NS & NS \\
\hline \multicolumn{4}{|l|}{ Nitrogen levels } \\
\hline $80 \%$ RDN (120 kg N & 112.78 & 11.18 & 249.57 \\
\hline $90 \%$ RDN (135 kg N) & 110.34 & 14.27 & 261.28 \\
\hline $100 \%$ RDN (150 kg N) & 113.14 & 16.59 & 249.46 \\
\hline $110 \%$ RDN (165 kg N) & 114.18 & 17.09 & 263.5 \\
\hline $\mathrm{CD}(\mathbf{p}=\mathbf{0 . 0 5})$ & NS & NS & NS \\
\hline
\end{tabular}

(Soil N, P and K status before sowing was $121 \mathrm{~kg} \mathrm{~N}, 17 \mathrm{~kg} \mathrm{P}_{2} \mathrm{O}_{5}$ and $375 \mathrm{~K}_{2} \mathrm{O} \mathrm{ha}^{-1}$ respectively)

\section{Phosphorus content and uptake}

The data presented in Table 2 showed that $\mathrm{P}$ content and uptake in grain of wheat showed significant relation with the different $\mathrm{N}$ levels. But varying $\mathrm{N}$ sources did not have any significant effect on $\mathrm{P}$ content and uptake by grain and straw of wheat. Similarly, varying
$\mathrm{N}$ levels did not significantly influence $\mathrm{P}$ content and uptake in straw of wheat. Among different $\mathrm{N}$ levels, application of $110 \% \mathrm{RDN}$ being at par with $100 \%$ RDN resulted in significantly higher $\mathrm{P}$ content and uptake in grain and total $\mathrm{P}$ uptake than rest two treatments (80 and $90 \% \mathrm{RDN}$ ). Increase in uptake of $\mathrm{P}$ was mainly due to the reason that 
nutrient uptake by any crop followed the yield pattern which increased with increasing $\mathrm{N}$ levels. Katiyar and Uttam (2003) reported that the higher fertility levels increased the concentration and uptake of $\mathrm{P}$ in grains and straw. Kumar (2005) also reported that highest phosphorus uptake in grain was observed by the application of $125 \%$ of recommended dose of nitrogen and also highest phosphorus uptake by stover is obtained with $125 \%$ RDN.

\section{Potassium content and uptake}

The data pertaining to $\mathrm{K}$ content (per cent) and uptake $\left(\mathrm{kg} \mathrm{ha}^{-1}\right)$ in grain and straw of wheat (Table 3 ) indicate that different sources and levels of $\mathrm{N}$ fail to influence $\mathrm{K}$ content in straw and $\mathrm{K}$ uptake in grain, straw and total $\mathrm{K}$ uptake. Among different $\mathrm{N}$ sources application of three split application of neem coated urea $(1 / 2$ Basal $+1 / 4$ first irrigation $+1 / 4$ heading)] being at par with two split application of neem coated urea ( $1 / 2$ Basal $+1 / 2$ first irrigation) recorded significantly higher $\mathrm{K}$ content in grain of wheat. In the present investigation, significantly higher $\mathrm{K}$ uptake in grain and straw and total $\mathrm{K}$ uptake was recorded with $100 \% \mathrm{RDN}$ which was at par with $110 \%$ RDN but significantly higher than other two treatments ( 80 and $100 \%$ RDN). Similar were the findings of Katiyar and Uttam (2003).

\section{Soil studies}

Nitrogenous fertilizer plays an important role in deciding wheat yield, but its application rates vary greatly, and there is a lack of data to quantify the residual effects of $\mathrm{N}$ levels on soil $\mathrm{N}$ availability. Perusal of data in table 4 pertaining to soil $\mathrm{N}, \mathrm{P}$ and $\mathrm{K}$ status after harvesting of wheat revealed that various nitrogen levels and sources fail to influence $\mathrm{N}, \mathrm{P}$ and $\mathrm{K}$ status of soil after harvesting of wheat.
It could be concluded that application of three split application of neem coated urea $(1 / 2$ Basal $+1 / 4$ first irrigation $+1 / 4$ heading)] recorded significantly higher $\mathrm{N}$ content and uptake in grain and straw, $\mathrm{K}$ uptake by straw, total $\mathrm{N}, \mathrm{P}$ and $\mathrm{K}$ uptake and $\mathrm{K}$ content in grain. Increasing nitrogen levels from 80 to $110 \%$ RDN resulted in significantly higher $\mathrm{N}, \mathrm{P}$ and $\mathrm{K}$ content in grain and $\mathrm{N}$ content in straw and also higher $\mathrm{N}$ and $\mathrm{P}$ uptake in grain, $\mathrm{N}$ and $\mathrm{K}$ uptake in straw and total $\mathrm{N} \mathrm{P}$ and $\mathrm{K}$ uptake. Available N, P and K status of soil after the harvest of wheat was not influenced significantly due to various nitrogen sources and levels.

\section{References}

IPCC, 2014: Climate Change 2014: Synthesis Report. Contribution of Working Groups I, II and III to the Fifth Assessment Report of the Intergovernmental Panel on Climate Change [Core Writing Team, R.K. Pachauri and L.A. Meyer (eds.)]. IPCC, Geneva, Switzerland, 2014; 151 pp.

Katiyar, A.K., \& Uttam, S.K. (2003). Effect of fertility levels \& weed control practices on nutrient uptake \& yield of rainfed barely in eroded soil of central Uttar Pradesh. Indian Agriculturalist, 52(1\&2), 17-21.

Kumar, M., Singh, H., Hooda, R.S., Khippal, A.K., Singh, T., \& Sheoran, P. (2002). Effect of genotypes and nitrogen levels on $\mathrm{N}, \mathrm{P}$ and $\mathrm{K}$ content and uptake by irrigated pearl millet [Pennisetum glaucum (L.) R.Br. Emend Stuntz.]. Research Crops, 3(3), 493-497.

Kumari A and Singh SK (2016) Impact of different tillage practices on soil organic carbon and nitrogen pool in rice-wheat cropping system. J Agri Search 3: 82-86.

Kumar, P. (2005). Effect of different nitrogen 
levels and biofertilizers strains on productivity and soil fertility in pearlmillet-wheat cropping system. $\mathrm{PhD}$ thesis, Chaudhary Charan Singh Haryana Agricultural University, Hisar, Haryana.

Ladha J K, Singh Y, Erenstein O and Hardy B (Eds.) (2009) Integrated crop and resource management in the rice-wheat system of South Asia. International Rice Research Institute, Los Banos, Philippines

Muurinen, S. (2007). Nitrogen dynamics and nitrogen use efficiency of spring cereals under Finnish growing conditions. Yliopistopaino, 29, 1-38.

Prasad R (2011) Nitrogen and food grain production in India. Indian J Ferti 7: 66-76.

Taalab, A.S., Mahmoud, A., \& Siam, S. (2015). Implication of rate \& time of nitrogen application on yield \& nitrogen use efficiency of barley in sandy soil. International Journal of Chemical Technology Research, 8(6), $412-422$.

\section{How to cite this article:}

Meena Sewhag, Shweta, Parveen Kumar, Manoj Kumar Sharma, Neelam and Uma Devi. 2020. Nutrient Studies of Wheat as Influenced by Different Nitrogen Management Practices. Int.J.Curr.Microbiol.App.Sci. 9(11): 161-167. doi: https://doi.org/10.20546/ijcmas.2020.911.019 